\title{
Distribution and conservation status of four Myrmotherula antwrens (Formicariidae) in the Atlantic Forest of Brazil
}

\author{
BRET M. WHITNEY and JOSÉ FERNANDO PACHECO
}

\section{Summary}

We review the distribution and habitat of four Myrmotherula antwrens endemic to the Atlantic Forest of eastern Brazil, and present data to correct and update the information available in the literature. Based primarily on field experience over the past several years, we show that these birds are highly threatened despite having been recorded in several reserves. The chief issue affecting the continued survival of these Myrmotherulas is that very little lowland (i.e. below $300 \mathrm{~m}$ ) forest is included in the reserve system, and almost none exists outside the protected areas. Those lowland forests that do exist, both within and outside of reserves, are invariably under greater human pressure than the much more extensive forests of the adjacent uplands, and are disappearing at a much greater rate. With the aim of protecting not only these Myrmotherulas but also the entire lowland fauna of the Atlantic Forest, we recommend that funding for a significant and monitored increase in the guard system be made available to help ensure the integrity of the existing forest reserves into the future. As probably the single most important lowland forest patch in Espírito Santo/Rio de Janeiro that does not have official reserve status, we highly recommend that negotiation to establish "Fazenda União" in northern Rio de Janeiro as a carefully maintained protection area be initiated immediately, before the possibility to preserve it passes.

Apresenta-se uma resenha da distribuição e habitat de quatro espécies endêmicas do gênero Myrmotherula da Mata Atlântica e também dados para corrigir e atualizar a informação disponível em literatura. Baseando-se principalmente na experiência de campo dos autores durante os últimos anos, evidências são fornecidas para demonstrar que a sobrevivência destas espécies está claramente ameaçada a despeito da ocorrência destas em diversas unidades de conservação existentes ao longo de suas distribuições. $O$ dado mais relevante que interfere diretamente na continuada sobrevivência destas formas é que muito pouco das florestas baixo-montanas estão inseridas no sistema de unidades de conservação ao longo da Serra do Mar e mesmo quase nada existe destes ambientes fora das reservas. Estas porções de floresta nas baixadas ou em cotas inferiores a $300 \mathrm{~m}$ quando existem, fora ou dentro das unidades de conservação, estão invariavelmente sob maior pressão humana e assim desaparecendo em muito maior proporção do que as mais extensas florestas montanas adjacentes. Dentro de uma perspectiva conservacionista não somente destas quatro espécies de Myrmotherula mas de toda fauna da Mata Atlântica de baixas altitudes recomenda-se o investimento monitorado a longo prazo de um expressivo sistema de guarda-parques para garantir a integridade das unidades de conservação existentes permanentemente. Recomenda-se especialmente também a negociação imediata para o estabelecimento da Fazenda União 
no norte do Estado de Rio de Janeiro como unidade de conservação para que esta área, provavelmente o mais importante trecho de floresta não preservada legalmente dos estados Espírito Santo/Rio de Janeiro, desapareça antes da sua possibilidade de preservação.

\section{Introduction}

The Atlantic Forest of eastern Brazil holds one of the most highly endemic and at the same time most endangered avifaunas in the world, with approximately 170 forest species (non-forest species not included in this total) and about 23 genera restricted to the region as it was defined by Scott and Brooke (1985). Of these, 51 species $(30 \%)$ were judged sufficiently endangered to be included in Collar et al. (1992). The avifauna consists of distinct lowland and highland elements, with about $130(76 \%)$ of the endemic species (and all but one of the genera, Ramphodon) largely restricted to the humid montane forests, and about 40 species $(24 \%)$ occurring principally in the lowlands. Of these 40 lowland endemic species, $20(50 \%)$ were included in the treatment of Collar et al. (1992), while only $18 \%$ of the endemic highland avifauna was judged to be highly threatened. This is an alarming if not surprising realization, as forest clearance on the coastal plain has been much more intensive and extensive than has habitat alteration in the nearby mountains.

More endemic species are contained in the antwren genus Myrmotherula than in any other avian genus in the lowland Atlantic Forest. Five endemic species occur between Alagoas in the north and Rio Grande do Sul in the south, with the highest diversity in the restricted region between southern Bahia and southern São Paulo. One of these, Rio de Janeiro Antwren M. fluminensis, remains known only from the unique type mist-netted in July 1982 in a disturbed woodlot at $20 \mathrm{~m}$ elevation in central Rio de Janeiro state (Gonzaga 1988). The other four species, Salvadori's Antwren M. minor, Unicolored Antwren M. unicolor, Alagoas Antwren $M$. snowi (here considered a species separate from $M$. unicolor), and Band-tailed Antwren $M$. urosticta, have received little attention in the literature. Additionally, the only other member of the genus inhabiting the lowland Atlantic Forest, White-flanked Antwren $M$. axillaris, is represented by the highly isolated, distinctive subspecies luctuosa, which our studies indicate is specifically distinct from relatives further west (Isler et al. in prep.). The lower montane zone of the Atlantic Forest between central Espírito Santo and extreme northern Rio Grande do Sul (at Taquara, at least historically) is inhabited by Star-throated Antwren M. gularis, which is not considered a lowland species for the purposes of this paper, although it should be noted that gularis does reach sea-level very locally in southern Rio de Janeiro and northern São Paulo, where the Serra do Mar rises almost directly out of the sea.

Modern statements of the range of these Myrmotherula species are often in error or incomplete, and none takes into account the overwhelming loss of habitat that has occurred in just the past few decades. In the absence of these baseline data, it is not possible to identify and implement effective conservation measures. Our fieldwork over the past several years indicates that an up-to-date assessment of the conservation status of these antwrens is needed. In this paper 
we clarify the distribution, basic habitat requirements, and/or conservation status of $M$. minor, $M$. unicolor, $M$. snowi and $M$. urosticta, and provide some thoughts concerning the survival outlook for these species.

Distribution maps were based on published and unpublished specimen localities, our own records (usually documented with tape recordings), and sight records of some others. We do not pretend to have located every specimen and sight-record of these species (we expect that we are missing a few old specimens of $M$. unicolor, especially), but we probably have located almost all of them. The Appendix provides names and original sources for localities, and indicates which of these are documented (either specimen[s] or tape recordings). Coordinates for some localities are from Paynter and Traylor (1991), and Vanzolini (1992).

\section{Salvadori's Antwren Myrmotherula minor Salvadori, 1864}

\section{Distribution and habitat}

Recent systematic lists (such as Meyer de Schauensee 1966, Sibley and Monroe 1990) include north-eastern Peru in the range of $M$. minor, apparently based at least in part on a single immature male specimen tentatively identified as this species by Zimmer (1932), and Amazonian Brazil on the Rio Purus, evidently based on a single immature male identified as this species by Snethlage (1908) and by Hellmayr (Cory and Hellmayr 1924). Sick (1993) considered these records unconfirmed, and D. F. Stotz (in litt.), who has examined the Peruvian specimen discussed by Zimmer (1932), believes that it is not referable to $M$. minor, and also writes that the wing measurement of the Rio Purus immature male provided by Hellmayr (51.7 mm: Cory and Hellmayr 1924) is "a bit long for even an adult minor," and that Snethlage's (1908) wing measurement of $55 \mathrm{~mm}$ is much too long for minor. Zimmer (1932) also discussed a female specimen from Rio Avila, Ecuador, that he believed could represent $M$. minor. This specimen is currently identified as a Plain-winged Antwren M. behni (D. F. Stotz in litt.).

Hilty and Brown (1986: 395) reported that $M$. minor occurs in north-eastern Peru ("Iquitos eastward"), and south of the Amazon opposite Leticia, Colombia, in "varzea forest midlevels with mixed-species flocks." This notwithstanding, much modern fieldwork in upper Amazonia (especially in north-eastern Peru east of Iquitos), including several extensive collections of birds and the observations of numerous competent observers, has not recorded $M$. minor. There is, however, at least one "male" (adult male?) specimen of M. minor labelled as from Iquitos in the Academy of Natural Sciences, Philadelphia (ANSP), which D. F. Stotz (in litt.) believes is correctly identified but of doubtful provenance. This specimen was collected by the English naturalist Whiteley (Henry Whiteley, Jr or his son), who may have worked extensively in eastern Brazil, and whose specimen labels (apparently often not those of the original collector) have been judged erroneous in some cases (Snow 1982). An apparent typographical mistake led to the inclusion of Pará (instead of Peru) in Sick's (1985) statement of the range of M. minor in "Alta Amazônia," which has been propagated by Bernardes et al. (1990) and, in turn, Oren (1992). Sick (1993) did not mention Pará in the range of $M$. minor. 
We recommend that until there is some undisputed evidence of its occurence outside the Atlantic Forest region, $M$. minor be considered endemic to the lowland forests of south-eastern Brazil. It definitely occurs from near Santa Teresa in central Espírito Santo south to extreme north-eastern Santa Catarina (one old specimen), with a single old specimen from far south-eastern Minas Gerais. Sick (1985: 521, 1993: 406) included $M$. minor in a list of formicariids he and others recorded in the Boa Nova area ("Rio das Contas") of southern Bahia in 1977 and 1978, although he did not incorporate Bahia in the species account. Subsequently, Teixeira (1987) reported that $M$. minor inhabits the "mata-de-cipó" (a dry, viny woodland characterized by an abundance of terrestrial bromeliads) near Boa Nova, Bahia (about $625 \mathrm{~km}$ north of the nearest documented record), in the same habitat as Rhopornis ardesiaca (Slender Antbird). In the absence of documention supporting the occurrence of $M$. minor in southern Bahia, these Boa Nova records should be considered doubtful, as much work in this and other habitats at Boa Nova and elsewhere in southern Bahia suggests that $M$. minor does not occur in the region, almost certainly not in the mata-de-cipó.

Most modern records of $M$. minor come from the Serra da Bocaina and Serra do Mar of southern Rio de Janeiro and São Paulo. There are apparently no records of $M$. minor from far southern São Paulo. Mapped localities (Figure 1) probably cover all of the specimen records and virtually all of the sight records. J.F.P. has observed unidentified Myrmotherulas in several areas below $100 \mathrm{~m}$ elevation in Rio de Janeiro which may be referable to $M$. minor: Rio Preto, Campos; A.P.A. Cabiúnas, Macaé; A.P.A. Sapiatiba, São Pedro d'Aldeia; Barra do Rio Una, Cabo Frio; and Parque Municipal de Niteroi.

M. minor inhabits the interior of both undisturbed forest and old second growth in humid regions where trees are festooned with bromeliads and other epiphytic growth, and mosses coat some of the trunks and limbs in the shady undergrowth. Old specimens from Cantagalo and Muriaé in the lower Paraiba River region must have come from tropical semi-deciduous forest ("floresta subcaducifólia tropical": Carauta and Rocha 1988), but no significant patch of this habitat exists today (J.F.P. pers. obs.). Second-growth seems to be tolerated only if it is well developed and connected to a block of essentially mature forest. Extensive mist-netting and observation in a small second-growth forest that was directly connected to mature forest upslope near Majé, Rio de Janeiro (where $M$. minor may reasonably be expected to occur) failed to produce a single record of $M$. minor, although $M$. axillaris and $M$. unicolor were both captured frequently (L. P. Gonzaga verbally 1994). Isolated patches of young second growth (canopy height less than about $7 \mathrm{~m}$ ) do not appear to be suitable, but this requires further study to establish. In our experience, $M$. minor is almost always near water, whether in low, swampy forest, or close to rushing streams on steep, forested slopes. Old specimens from near Santa Teresa in Espírito Santo were reported from as high as $780 \mathrm{~m}$ (specimen in Museu Nacional do Rio de Janeiro [MNRJ] collected and tag annotated by H. Sick in 1939). Scott and Brooke (1985) listed M. minor as reaching $500 \mathrm{~m}$ elevation in the Serra do Tinguá above the city of Rio de Janeiro; all of our observations have been below about $300 \mathrm{~m}$. 


\section{Unicolored Antwren Myrmotherula unicolor Ménétries, 1835}

\section{Distribution and habitat}

M. unicolor is restricted to the lower slopes and coastal plain seaward of the Serra do Mar, from the northern end of this range in Rio de Janeiro south to the municipality of Osório (at least historically) in extreme northern Rio Grande do Sul (Belton 1985). Statements of the range that include Espírito Santo (Meyer de Schauensee 1966, Sibley and Monroe 1990) are based on the undocumented and probably erroneous records of A. Ruschi (1953; Pacheco et al. 1993). Although $M$. unicolor reaches $500 \mathrm{~m}$ elevation at least locally, the great majority of our and other records are from below about $200 \mathrm{~m}$.

In Rio de Janeiro state, we have found $M$. unicolor in undisturbed forest, moderately disturbed forest, and second growth of humid forest with a canopy height of 8-10 $\mathrm{m}$ and an abundance of vines and suspended dead leaves in the undergrowth. As with $M$. minor, $M$. unicolor does not seem to be able to survive in second growth that is not in close proximity to older-growth forest. It usually keeps to the interior of all habitats, but we have noted it at the edge (especially along roads through habitat) on a few occasions. From the Rio Ribeira valley of São Paulo south to about the Paraná border, in which region the coastal plain is broader, M. unicolor also inhabits restinga woodland on sand ridges, penetrating inland a short distance in the Rio Ribeira valley. The coastal restinga woodlands range in canopy height from about $8-12 \mathrm{~m}$, and generally have a dense, non-herbaceous understorey made up of thin trunks (most less than about $10 \mathrm{~cm}$ diameter at breast height) and vines. In this region, unicolor is the only Myrmotherula in the restinga. It is, however, absent from coastal restingas in Rio de Janeiro. We suspect that this may be explained by the presence in Rio de Janeiro restingas of $M$. axillaris, which is here near the southern terminus of its range. Myrmotherula unicolor and axillaris are syntopic (sometimes in the same mixed-species flocks) in northern Rio de Janeiro forest habitats, which suggests that the structurally more simple and geographically restricted coastal restinga is not able to support both species.

From southern São Paulo southward, restingas are replaced by taller, more humid forest under the climatic influence of the Serra do Mar, which in this region once again descends practically to the coast. Most sites in which we have found M. unicolor (excepting the well-drained restinga woodlands) are humid, with streams and small rivers in the immediate vicinity.

In the southernmost portion of its range, $M$. unicolor has not been recorded between Blumenau in Santa Catarina and Torres in northern Rio Grande do Sul, a gap of approximately $400 \mathrm{~km}$. This area was apparently never visited by collectors and today, according to Bege and Marterer (1991), the native habitats are largely converted to agriculture and livestock raising. Although it is possible that this is a true hiatus in the distribution of $M$. unicolor, we think it is more likely that a lack of fieldwork when appropriate habitat existed explains the anomaly. 


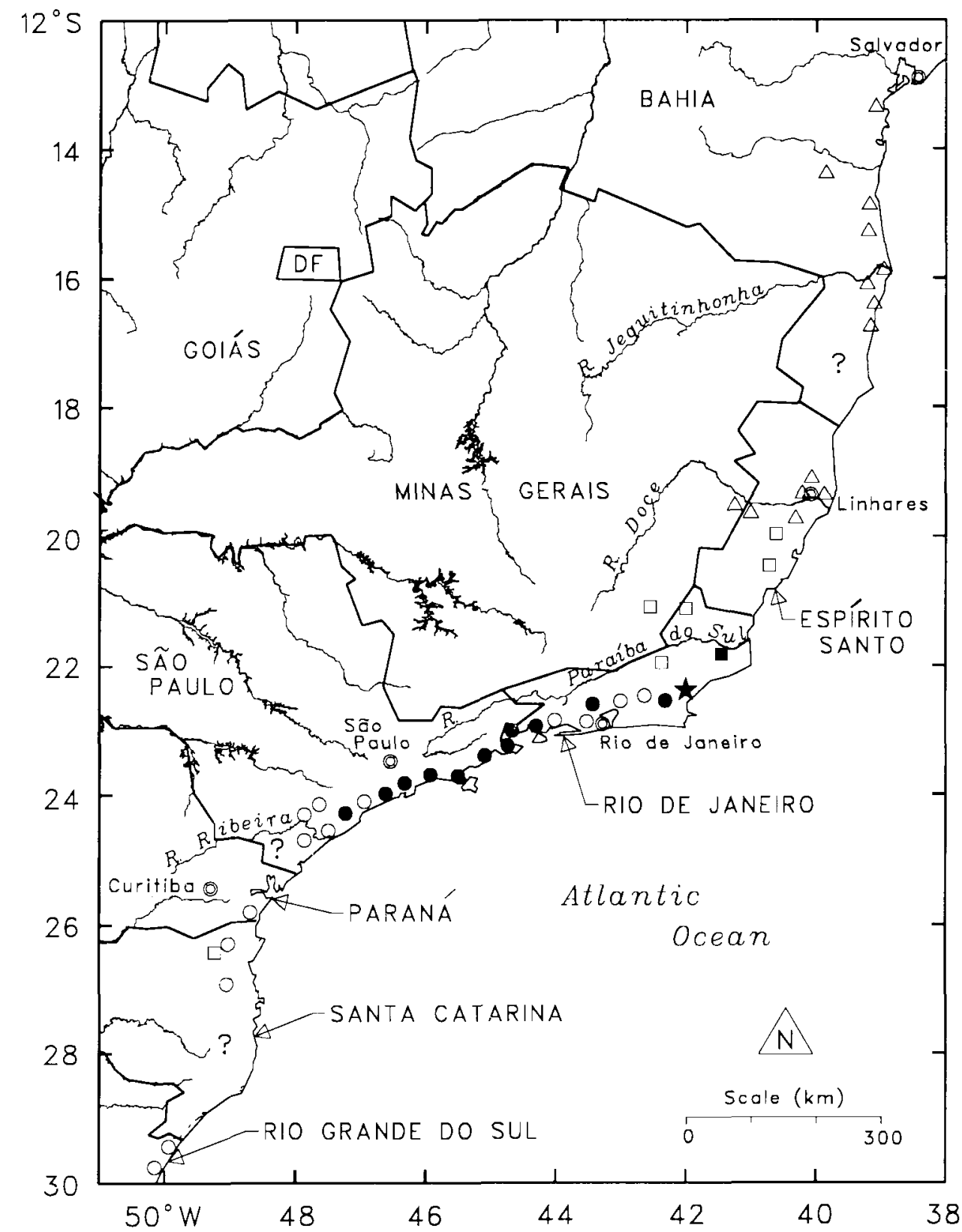

Figure 1. Distributions of three Myrmotherula antwrens in south-east Brazil: 23 localities for $M$. minor, 48 localities for $M$. unicolor and 22 localities for $M$. urosticta, many of which were provided for us by L. P. Gonzaga and N. J. Collar, who had compiled these data for possible inclusion in Collar et al. (1992). Localities within c.25 km of each other are mapped as a single point. Areas where only urosticta has been found are located by a triangle; where only minor has been found, by a square; where only tuicolor has been found, by a circle; where both urosticta and micolor have been found, by a black square; where both minor and unicolor have been found, by a black circle; and where all three species have been found, by a black star. The three? in southern Bahia, southern São 


\section{Alagoas Antwren Myrmotherula snowi Teixeira and Gonzaga, 1985}

\section{Distribution and habitat}

Mymotherula snowi is known only from the type locality, "Pedra Branca" (Collar et al. 1992) above Murici, Alagoas (approximately $9^{\circ} 15^{\prime} \mathrm{S} 35^{\circ} 50^{\prime} \mathrm{W}$; see map in Teixeira and Gonzaga 1985). The absence of specimens (or sightings) in the coastal lowlands of north-eastern Brazil, where much investigation has been conducted both historically and in recent decades, indicates that $M$. snowi is indeed restricted to upland forests (approximately $550 \mathrm{~m}$ ) as reported by Teixeira and Gonzaga (1985).

The Borborema Plateau of interior north-eastern Brazil extends eastward in several upland spurs to within about $50 \mathrm{~km}$ of the coast in Alagoas. Moisture-laden winds off the Atlantic have permitted the historic maintenance of semi-humid forest above about $500 \mathrm{~m}$ on these isolated serras, whereas uplands just a few kilometres inland are in the rainshadow of the escarpment, and thus subject to a more severe dry season. Fragments of this semi-humid forest in Alagoas today represent the only habitat for $M$. snowi, though it is currently known from only a single such fragment.

\section{Band-tailed Antwren Myrmotherula urosticta Sclater, 1857}

\section{Distribution and habitat}

M. urosticta is known from as far north as approximately $25 \mathrm{~km}$ north of Valença, Bahia (pers. obs.), to as far south as "Fazenda União" near Rocha Leão, Rio de Janeiro, from which state the species has not definitely been reported previously (tape recording by J.F.P. and P. S. M. da Fonseca), and one old specimen from extreme eastern Minas Gerais. L. P. Gonzaga (in litt. 1990) located a single specimen of $M$. urosticta collected in the late 1800 s by $A$. Fry in the British Museum that is labelled from Rio de Janeiro. Sharpe (1906) stated that during this period Fry worked in the vicinity of the city of Rio de Janeiro and collected 947 bird specimens, without reporting that he travelled outside the state. We see no reason to doubt that this specimen was collected somewhere near the city of Rio de Janeiro; it has apparently been overlooked in the past. The apparent distributional gap in far southern Bahia and northern Espírito Santo is, we believe, probably due to a lack of investigation, although it is clear that $M$. urosticta is not uniformly distributed in tall forest in Espírito Santo today (see below).

Paulo and southern Santa Catarina indicate apparent (possibly artifactual) gaps in the range of urosticta, minor and unicolor respectively. Names, coordinates and references for localities are listed in the Appendix. Note that some localities are represented by old specimen records. Forest clearance and fragmentation have been so intensive, especially in the past four decades, that many of these old localities are no longer suitable for these antwrens, and large areas of potentially suitable forest from which these species were never recorded are gone. 
Myrmotherula urosticta inhabits primary or moderately disturbed forest. To date, we have not found it in second growth with a canopy height of less than about $15-20 \mathrm{~m}$. The Atlantic Forest at Sooretama Biological Reserve, which is situated on a plateau with sandy soil and which undergoes a variable dry season with annual rainfall averaging less than $1,000 \mathrm{~mm}$, is classified as "evergreen seasonal forest" ("Floresta dos Tabuleiros": IBDF 1981). Myrmotherula urosticta is fairly common at Sooretama, but is rare in the adjacent but very slightly lower-elevation forest of the Rio Doce ("Linhares") Forest Reserve of the Companhia Vale do Rio Doce (CVRD). Other species that are rare or apparently absent from Linhares but fairly common at Sooretama include Yellow-legged Tinamou Crypturellus noctivagus, Striated Softtail Thripophaga macroura, Cinereous Antshrike Thamnomanes caesius and Scalloped Antbird Myrmeciza ruficauda. A relative study of such characteristics as soil composition and forest structure (canopy heights, abundance and distribution of light gaps, abundance of vines and other plant groups) of these neighbouring reserves, together with a comparison of their avifaunas (both of which are well known relative to most iorests in south-eastern Brazil), would be a worthwhile and informative pursuit. Other forests in which we have found $M$. urosticta in northern Rio de Janeiro ("Fazenda União"; Desengano State Park) and southern Bahia (near Valença; CVRD forest reserve at Porto Seguro; and Itatingui), although not among the most humid forests of eastern Brazil (for example, they are not rich in bromeliads or other epiphytic growth), seem to us to be more structurally complex than the Sooretama forest. M. urosticta does not seem to be partial to streams or other water, as most of our observations have been some distance from the nearest water.

\section{Conservation status and comments}

Myrmotherula minor, $M$. unicolor and $M$. urosticta have received little or no attention in the conservation literature. Scott and Brooke (1985) published the only abundance estimates and elevational data for these species from a limited area censused in 1980 and 1981. All three were included in a "near-threatened" list (Collar et al. 1992), which identifies those species "which, while apparently not (yet) seriously in danger of global extinction, give cause for concern." Although $M$. minor is officially listed as threatened with extinction in Brazil (Bernardes et al. 1990) and was almost given a species account in Collar et al. (1992; L. P. Gonzaga verbally 1994), its conservation status has not been described.

Our analysis of the historic and current probable distributions of $M$. minor, unicolor and urosticta, considered in the context of ( 1 ) the amount of appropriate habitat extant within reserves and private protection areas and (2) the outlook for the coming 10-20 years, has made it apparent that virtually the entire populations of these species are indeed in serious danger from loss of habitat. A review of the existing protection areas that hold some lowland forest between Salvador, Bahia and northern Rio Grande do Sul, thus covering completely the modern known distributions of all three of the near-threatened antwrens, serves to open a discussion of the conservation status of these birds. Grouping of 
reserves into two levels of effectiveness of protection by legal definition follows Câmara (1991).

Of the 27 forest protection areas that afford the highest level of legal and, usually, physical safety (national parks, and biological reserves and ecological stations on the state and federal levels, ranging in size from 1,500 to 315,000 ha), M. minor is known from five, unicolor from six (three overlapping with minor), and urosticta from three. Of the additional 16 protection areas in excess of 500 ha that are officially established but the use and possible development of which is not restricted by their legal definition (ecological reserves, environmental protection areas ["APAs"], private reserves, areas designated for governmental safekeeping or "tombamento," etc.), minor is known from none (three are within its range), unicolor from none (four are within its range, none overlapping with those for minor), and urosticta from three (two of which are managed by CVRD). From these figures, one can deduce that (1) many of the 43 areas have not been inventoried very thoroughly or (2) most of them do not have habitat suitable for these antwrens. We believe that a combination is involved, but that the operative problem for all three species, especially minor and unicolor, is that almost none of the existing protection areas includes sufficient forest in the prescribed elevational range, i.e. below about $300 \mathrm{~m}$. In the following paragraphs we discuss the effectiveness of the extant forest reserves in protecting these antwrens, and describe some significant forest areas that are not officially protected. We wish to emphasize throughout that very little well developed lowland forest exists outside the reserve system, especially in the most critical region (for these antwrens) between southern Bahia and southern São Paulo, and that almost none of what is left may be realistically expected to survive the next decade or two without active protection now. The potentially most important localities in the Atlantic Forest and related habitats (restingas, etc.) that are not currently afforded any legal protection but which have been proposed for official establishment are listed, with baseline data on their status, in the annals of the workshop of the Fundação SOS Mata Atlântica (1990).

Myrmotherula minor is undoubtedly the most immediately endangered of the three near-threatened antwrens. Six specimens from the Santa Teresa/ Leopoldina area of southern Espírito Santo, and T. A. Parker's (verbally to B.M.W. 1989) single sight-record of the species in the early 1980s at Augusto Ruschi (formerly Nova Lombardia) Biological Reserve may on the surface suggest that $M$. minor has a refuge there, but all of these records are dated (see Appendix; even 10 years is a long time when one talks about the survival of forest in south-eastern Brazil). We have not found M. minor at Augusto Ruschi or anywhere in the vicinity, and we know of no other documented records of it from the reserve. Today there is almost no well developed forest in southern Espírito Santo below about $700 \mathrm{~m}$ (C. E. de Carvalho verbally 1988), which is near the upper elevational limit for minor. Owing to the inadequate plumage descriptions of $M$. minor in the literature, occasional reports of it from Sooretama Biological Reserve are almost certainly misidentifications of $M$. axillaris luctuosa which, relative to generally more familiar Amazonian and Central American subspecies of axillaris, has reduced white in the flanks and a conspicuous white tail tip. Modern reports of minor from Augusto Ruschi must also carefully eliminate $M$. a. luctuosa from consideration. 
The outlook in Rio de Janeiro (from which state south we may effectively discuss the status of $M$. minor and unicolor as one) is little brighter. The only protected areas harbouring populations of $M$. minor are Poço das Antas and Tinguá Biological Reserves. Mymmotherula minor and unicolor were considered fairly common in 1981 at Poço das Antas by Scott and Brooke (1985), but habitat there is largely second-growth swamp-forest with a restricted area of taller forest (pers. obs.) and is probably not optimal for either species. Additionally, Poço das Antas is chronically threatened by the spread of fire from neighbouring fazendas. Burned areas then usually promote the growth of thick grass that inhibits the regeneration of native vegetation. At Tinguá, minor was judged uncommon below $500 \mathrm{~m}$ by Scott and Brooke (1985), who reported that the bulk of the 25,000 ha forest there was above $500 \mathrm{~m}$, with large areas of cleared land and substantial patches of maturing secondary forest' up to about $750 \mathrm{~m}$. The fact that this forest protects a watershed benefiting the city of Rio de Janeiro provides some hope for the survival there of $M$. minor, but it is a certainty that the lower-elevation forests will continue to receive the brunt of whatever population pressures affect the area. Myrmotherula minor has not been found at Desengano State Park despite extensive avifaunal surveys there. The area of the park in which unicolor was found and in which minor would be most likely to occur is now mostly deforested and, in the absence of active protection, which seems unlikely to be initiated, cannot be expected to persist. Mymmotherula unicolor is known from a handful of sightings from the lowest reaches of Serra dos Órgãos National Park, but this area is almost all second growth quite limited in extent, and has suffered over the past several years from further habitat degradation (J.F.P. pers. obs.).

Both species and $M$. urosticta are known from "Fazenda União" near Rocha Leão in northern Rio de Janeiro. This important forest, which encompasses roughly 3,000 ha and has an elevational gradient from 10 to $350 \mathrm{~m}$, is owned by the Rede Ferroviaria Federal S.A. (RFFSA), and is maintained primarily as a source of timber for railroad ties. Although the RFFSA restricts access to Fazenda União, it is not officially protected.

The single, old specimen of $M$. minor from the presumably tall, semi-deciduous forests near Cantagalo in the lower Paraiba River valley bespeaks a sad story. C. Euler (1900: 132), who lived at Cantagalo for several years, recounted the almost complete loss by the 1860 s of a rich avifauna, which included Red-billed Curassow Crax blumenbachii, Black-fronted Piping-guan Pipile jacutinga, Red-and-green Macaw Ara chloropterus and Rufous-vented Ground-cuckoo Neomorphus geoffroyi. This remarkable forest is apparently represented today only by small, highly disturbed fragments on hilltops. $M$. minor is possibly extinct from this significant portion of its range, the most similar habitat in which it has been located recently being an unprotected, remnant forest (about 100 ha) near Itaperuna. It probably never occurred in the middle or upper Paraiba valley, as is the case for such lowland species as Black-necked Aracari Pteroglossus aracari, Lined Antshrike Thamnophilus palliatus, M. axillaris, Rufous-winged Antwren Herpsilochmus rufimarginatus and Yellow-green Grosbeak Caryothraustes canadensis.

In the lowlands and foothills of the Serra da Bocaina of southern Rio de Janeiro and northern São Paulo, where steep forested slopes practically meet 
the sea, M. minor and M. unicolor find their northernmost strongholds. This part of the Brazilian coast has become easily accessible to people only in the past 20 years or so: signs of this are apparent all along the highway, as almost all of the forest below the base of the slopes has been cleared or heavily disturbed. The area around São Roque in coastal southern Rio de Janeiro is a typical example of the uphill retreat of the forest in the face of a growing human population: it still holds some primary forest, and the lower slopes of the mountains there are still extensively forested, but the government has designated the region for agrarian reform. We have seen the São Roque lowland forest reduced drastically in the past four years, and it is almost certainly going to be completely deforested in the coming decade. Some good forest exists, presumably as a sort of security zone, on the property of the Angra Nuclear facility at Itaorna, and would make an excellent reserve if extended from the coast to the mountains a few kilometres inland.

The 100, ooo ha Serra da Bocaina National Park is centred in the mountains and unfortunately encompasses little lowland forest habitat. This is the case with most of the parks in the Atlantic Forest: lower limits are frequently 200, 400 , or $600 \mathrm{~m}$. To protect species like M. minor and unicolor (and many other lowland endemic birds) adequately, Bocaina should be extended down to cover several selected areas that are presently forested, and perhaps some others that could regenerate to well-developed forest in a few decades. The 315,00o-ha Serra do Mar State Park, which extends roughly from the Rio de Janeiro border south to Pedro de Toledo in São Paulo, is probably the single most important reserve for both $M$. minor and $M$. unicolor. The area approximately $22 \mathrm{~km}$ south of Ubatuba known as Corcovado is within this park, but there are no signs or guards to indicate that the area is protected. This site should be actively guarded, as it is one of the few extensive lowland forests that is directly connected to the forested mountain slopes, protecting a complete transect of habitats in the Serra do Mar. Ilha do Cardoso State Park $(22,500$ ha) is a particularly important conservation area for lowland birds. D. F. Stotz (in litt. to L. P. Gonzaga 1988) reported that $M$. unicolor is uncommon there. As long as significant forest below about $500 \mathrm{~m}$ exists in the Serra do Mar region, viable populations of $M$. minor and M. unicolor should survive. With this end in mind, private efforts to conserve forested areas, such as "Fazenda Capricornio" near Ubatuba, and "Fazenda Intervales", which connects Carlos Botelho State Park with Xitué Ecological Station and the Alto Ribeira State Tourist Park in southern São Paulo, should be recognized and encouraged by the government and the tourism industry.

Southward within the range of $M$. minor and $M$. unicolor, there is still significant forest above the coast of northern Paraná (above Guaraqueçaba, mostly on steep slopes) and, at least as recently as 1989, north-west of Joinville, Santa Catarina (near the Paraná border). These areas have much conservation potential for these antwrens and other birds.

The comments of Willis and Oniki (1992) concerning recreational development and other threats to the integrity of the sand-ridge restingas of São Paulo are poignant with regard to the local population of $M$. unicolor.

M. urosticta has undoubtedly suffered severe, perhaps irrecoverable, setbacks in the southern portion of its range, basically from Sooretama Biological Reserve 
south. There is an old record from the Rio Manhuaçu, a small tributary of the Rio Doce, in extreme eastern Minas Gerais, but this region has been totally deforested (Fonseca 1985). Further up the valley, at the present site of the Rio Doce State Park, M. urosticta did not feature in a large collection of birds made in 1940. Although extensive deforestation in the region was already well under way (Pinto 1945: 315), and the species may have been absent or missed, it has not been seen in this area since and quite possibly does not occur.

From Sooretama Biological Reserve north through the remainder of the range of M. urosticta, there are three important forest reserves in which the species is known to occur: Monte Pascoal National Park (generally listed as 22,500 ha); the CVRD forest reserve at Porto Seguro $(6,069$ ha) and the adjoining Porto Seguro State Forest Reserve ( 1,000 ha); and the Una Biological Reserve $(11,400$ ha). In $1980,8,627$ ha of mostly lowland forest were expropriated from Monte Pascoal National Park and demarcated as indigenous land called "Barra Velha" for a population of about 1,100 people (Gonzaga et al. 1986, Caldeiron 1993). The expropriated forest was quickly converted into timber and other saleable artefacts, so that none remained by 1986 (Gonzaga et al. 1986). In coastal southern Bahia there are four CEPEC reserves - in one of which, "Gregorio

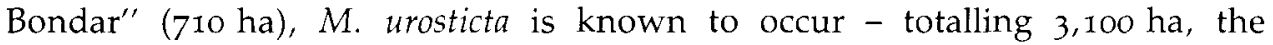
continued existence of which is much less secure than the above reserves, as they are set aside primarily for research on the cultivation of cacao. Several significant forest patches (in excess of about 500 ha) were noted from the air in the Porto Seguro area in January 1988 (B.M.W. pers. obs.), and the Atlantic Forest Workshop of the Fundação SOS Mata Atlântica (1990) proposed protection for at least five forest areas whose descriptions suggest they might be suitable for $M$. urosticta.

Given no more than the reserves that exist today, however, the survival of M. urosticta would appear to be dependent almost entirely on the preservation of approximately 21,500 ha of forest in four or five localities in southern Bahia, and Sooretama Biological Reserve and the CVRD Linhares Reserve in northern Espírito Santo. Even this is an optimistic figure, because we know that significant portions of these few reserves do not have appropriate habitat, although at least some of the second growth may eventually regenerate sufficiently.

Myrmotherula snowi, like the forest in which it barely survives, is probably a relict of a more humid epoch. The upland semi-humid forest that recently cloaked the eastern fringes of the Borborema Plateau is now virtually gone (pers. obs., November 1993). The account of the plight and conservation needs of $M$. snowi in Collar et al. (1992: 629-630 under account of Alagoas Foliage-gleaner Philydor novaesi), where it is designated highly endangered, adequately describes the gravity of its habitat and population threats. We can update that account by reporting that in 1992 the IBAMA/WWF Murici Biological Reserve was established to protect approximately 3,00o ha of forest, apparently including both tracts of land described in Collar et al. (1992), adjoining the type-locality of $M$. snowi and three other forest passerines described since 1983 . The main threat to this forest before establishment of the reserve, which is marked with signs and a metal chain across the main vehicular access track, was the extraction of timber. Fortunately, this activity seems to have stopped 
on a large scale (M. C. Souza verbally to J.F.P. 1992, F. Soares verbally to B.M.W. 1994), although we have observed local people collecting firewood in the reserve.

\section{Suggestions for the future}

Despite Keith Brown's call for the preservation of Fazenda União at the Atlantic Forest Workshop of the Fundação SOS Mata Atlântica in São Paulo in March/ April 1990, no action seems to have been taken. Fazenda União is not only the single known site at which all three of Myrmotherula minor, unicolor and urosticta survive, but it is also habitat for numerous other rare birds and appears to be an important wintering area for montane birds. We strongly recommend that negotiation with the RFFSA to purchase or in some way truly safeguard Fazenda União be initiated now so that this unique forest may be incorporated into the Brazilian system of biological reserves. Such negotiation may well have to allow for use that is inconsistent with the absolute integrity of the area, but if a meeting-ground can be found in which the survival of the forest in a reasonably well-developed state is the outcome (we can imagine several acceptable scenarios), then this must be viewed as a tremendous advance for conservation in the Atlantic Forest. Beyond the immediate preservation of the extant avifauna and other organisms, the potential utility of Fazenda União extends to the reintroduction of birds such as Solitary Tinamou Tinamus solitarius and Crax blumenbachii, and perhaps primates that have been extirpated or drastically reduced through hunting. On the establishment of the reserve, guards should be headquartered in Rocha Leão and posted at two or three major access points to the reserve.

A basic problem that confronts the preservation of forest outside of reserves is exemplified in the state of Rio de Janeiro. Technically, all of the Atlantic Forest in Rio de Janeiro is legally protected, and its utilization may only be done "under conditions that assure preservation of the environment" (Resolução Conjunta SEC/SEMAM N. oI Diário Oficial do Estado do Rio de Janeiro [Poder Executivo] de 25/04/90). Any cutting of timber or development of natural resources in the Atlantic Forest must first gain governmental approval. The "Batalhão Florestal", a branch of the State Military Police, is responsible for monitoring the preservation of forest and the hunting and trapping of wildlife. There is at least an infrastructure for enforcement of the law, but no educational programme to accompany it; this is left to the various non-governmental organizations (NGOs). Unfortunately, the Batalhão Florestal is chronically short of money for personnel and equipment, and is far short of its potential effectiveness; most of the NGOs are likewise underfunded. The net result is the steady loss of the resource, which extends even into official reserves, especially in the lowlands and in regions with limited topographic relief.

In our fieldwork over the past several years, we have noted that the CVRD properties set the standard for protection of forest reserves, primarily owing to the fact that they maintain a close personal presence (caretakers living on-site) in several different sectors of most reserves, and unannounced access is difficult. Numbers of guards are sufficient to ensure that patrols are regular, and significant felling of timber is unlikely to go unchecked for long. Such measures 
are and will become increasingly necessary to keep national parks and biological reserves intact, and we recommend that these basic elements (principally, numbers of guards and on-site caretakers) of the CVRD reserves be incorporated more widely in the forest protection system that exists in Brazil. In reserves protecting elevational gradients, lowland areas need the most surveillance because they are the access points and where clearing of the forest is most concentrated.

The hiring and maintenance of guards may be the most immediately effective, least complicated, and at the same time most economical forest/species protection measure available, and has the desirable side-effects of (1) providing income for families and thus, communities, in often particularly impoverished parts of the country, and (2) generating goodwill in the local population because several members of the community are integrally involved in the welfare of the reserve. Anything that can be done to generate goodwill and stimulate environmental awareness in the communities near reserves should be actively pursued. The NGO Fundação Nordeste, which involved the community of Quebrangulo, Alagoas, in the preservation of the forest now officially protected as Pedra Talhada Federal Biological Reserve, serves as a model for community-level conservation initiative.

Clearly, a relatively small but sustainable amount of monitored "maintenance" funding for local community education, a large number of new uniforms, and a few vehicles would go a long way toward ensuring that the forests on which we presently have a tenuous hold survive far into the future. The establishment of a new forest protection area is always cause for celebration. In the course of looking ahead to preserve ever more, however, we must not fail to guard existing areas: irreplaceable resources that are theoretically secure are being constantly eroded.

Finally, we wish to use the plight of these small antwrens to illustrate the general concept that informs our writing of this paper. It was mirrored in the sentiment of N. J. Collar, who expressed the view that, in compiling information for a book of the scope of Threatened birds of the Americas, there is no end, only an artificial stopping point (Collar et al. 1992: 13). That point having come, it is now time to bring to the forefront those priorities that are recognized in the field, keeping in mind that one is never too far ahead of the bulldozers.

\section{Acknowledgements}

We are grateful to L. P. Gonzaga and N. J. Collar for allowing us to cite records that they had compiled during research for Collar et al. (1992), and to D. F. Stotz for his informed opinion on the status of Myrmotherula minor in Amazonia and for his helpful comments on the manuscript in general. L. P. Gonzaga and T. S. Schulenberg also provided helpful criticism of the manuscript. We thank M. L. Isler for his comments on the manuscript and for preparing the distribution map from locality data we supplied, and C. E. de Carvalho, P. S. M. da Fonseca, and J. L. Rowlett for valuable assistance in the field. This paper is dedicated to the memory of Ted Parker, who loved the Atlantic Forest and these Myrmotherula antwrens. 


\section{Appendix. Names, coordinates and references for localities}

Localities are listed from north to south, and are shown in Figure 1. An asterisk $\left(^{*}\right)$ indicates a record documented with a specimen or tape recording. A zero (o) indicates a specimen record from before 1970 that has not been corroborated since. Abbreviations: MZUSP, Museu de Zoologia da Universidade de São Paulo; MNRJ, Museu Nacional do Rio de Janeiro; MCZ, Museum of Comparative Zoology; CMNH, Carnegie Museum of Natural History; BMW and JFP, authors; PSF, Paulo Sergio Fonseca; LPG, Luiz Pedreira Gonzaga; TAP, Theodore A. Parker III; DFS, Douglas Stotz; BA, Bahia; MG, Minas Gerais; ES, Espírito Santo; RJ, Rio de Janeiro; SP, São Paulo; PR, Paraná; SC, Santa Catarina; RS, Rio Grande do Sul.

\begin{tabular}{|c|c|c|c|}
\hline \multirow[t]{2}{*}{ Locality } & \multicolumn{2}{|c|}{ Coordinates } & \multirow[t]{2}{*}{ Source } \\
\hline & Lat.S & Long.W & \\
\hline \multicolumn{4}{|c|}{ Myrmotherula unicolor (Unicolored Antwren) } \\
\hline $\begin{array}{l}1 \text { S. Julião, Desengano State } \\
\text { Park, RJ }\end{array}$ & 2149 & 4139 & JFP \\
\hline 2 Faz. União, Rocha Leão, RJ & 2223 & 4200 & JFP \\
\hline 3 Cachoeiras de Macacu, RJ & 2228 & 4239 & JFP \\
\hline 4 Bananeiras, Silva Jardim, RJ & 2230 & 4223 & JFP \\
\hline 5 Poço das Antas Biol. Reserve, RJ & 2235 & 4217 & Scott \& Brooke, 1985 \\
\hline $\begin{array}{l}6 \text { Serra dos Orgãos National } \\
\text { Park, RJ }\end{array}$ & 2232 & 4259 & Scott \& Brooke, 1985 \\
\hline 7 Xerém, RJ & 2234 & 4318 & JFP \\
\hline 8 Citrolândia, Majé, RJ & 2236 & 4301 & $\begin{array}{l}\text { * Teix. \& Gonzaga, } \\
1985\end{array}$ \\
\hline 9 Tingua Biological Reserve, RJ & 2236 & 4326 & ${ }^{*}$ Scott \& Brooke, 1985 \\
\hline 10 Tijuca National Park, RJ & 2247 & 4314 & JFP \\
\hline $\begin{array}{l}11 \text { Serra de Madureira/Mendanha, } \\
\text { RJ }\end{array}$ & 2249 & 4330 & JFP \\
\hline $\begin{array}{l}12 \text { Pau da Fome, Rio de Janeiro, } \\
\text { RJ }\end{array}$ & 2255 & 4325 & * Sick \& Pabst, 1968 \\
\hline 13 Três Rios, Rio de Janeiro, RJ & 2256 & 4318 & * Sick \& Pabst, 1968 \\
\hline 14 Registo do Saí, RJ & 2256 & 4400 & o Pelzeln, 1868 \\
\hline 15 Mangaratiba, RJ & 2257 & 4402 & JFP \\
\hline 16 Angra dos Reis, RJ & 2300 & 4418 & Pacheco, 1988 \\
\hline 17 Tarituba, Parati, RJ & 2302 & 4434 & * BMW \\
\hline 18 São Roque, Parati, RJ & 2304 & 4441 & BMW \& JFP \\
\hline 19 Pedra Branca, Parati, RJ & 2313 & 4446 & ${ }^{*} \mathrm{MNRJ}$ \\
\hline 20 Ubatuba, SP & 2326 & 4504 & * Iher. \& Ihering, 1907 \\
\hline 21 Corcovado, Ubatuba, SP & 2329 & $45^{11}$ & * BMW \\
\hline $\begin{array}{l}22 \text { Boracéia Field Station } \\
\text { (MZUSP), SP }\end{array}$ & 2339 & 4554 & DFS (in litt.) \\
\hline 23 Varjão do Guaratuba, SP & 2345 & 4555 & * MZUSP, MNRJ \\
\hline 24 Estação Paranapiacaba, SP & 2347 & 4619 & o MZUSP \\
\hline 25 São Sebastião, SP & 2348 & 4525 & o Pinto, 1938 \\
\hline
\end{tabular}




\begin{tabular}{|c|c|c|c|}
\hline \multirow[t]{2}{*}{ Locality } & \multicolumn{2}{|c|}{ Coordinates } & \multirow[t]{2}{*}{ Source } \\
\hline & Lat.S & Long.W & \\
\hline 26 Estação Eng. Ferraz, SP & 2359 & 4636 & o MZUSP \\
\hline 27 Barra do Rio Corujas, SP & 2409 & 4739 & o MZUSP \\
\hline 28 Iporanga, SP & 2410 & 4740 & o MZUSP \\
\hline 29 Itanhaém, SP & 2411 & 4647 & * BMW \\
\hline 30 Morretinho, SP & 2413 & 4744 & o MZUSP \\
\hline 31 Poço Grande, Rio Juquiá SP & 2415 & 4737 & o MZUSP \\
\hline 32 Tamanduá, Rio Ipiranga, SP & 2416 & $475^{\circ}$ & o MZUSP \\
\hline $\begin{array}{l}33 \text { Pedro de Toledo (ex-Alecrim), } \\
\text { SP }\end{array}$ & 2417 & 4714 & o MZUSP \\
\hline 34 Peruíbe or Rio Guaraú SP & 2419 & 4700 & ${ }^{*}$ MZUSP \\
\hline 35 Barra do Rib. Onça Parda, SP & 2419 & $475^{1}$ & o MZUSP \\
\hline 36 Ribeirão Fundo, SP & 2420 & 4745 & o MZUSP \\
\hline 37 Sete Barras, SP & 2423 & 4755 & * Willis \& Oniki, 1981 \\
\hline 38 Barra do Rio Ribeira, SP & 2438 & 4724 & o MZUSP \\
\hline 39 Primeiro Morro, SP & 2442 & $475^{\circ}$ & o MZUSP \\
\hline 40 Iguape, SP & 2443 & 4733 & o Iher. \& Ihering, 1907 \\
\hline 41 Ilha do Cardoso State Park, SP & 2508 & 4758 & DFS (in litt.) \\
\hline 42 Cubatão, PR & 2550 & 4848 & o Straube, 1990 \\
\hline 43 Cabaraquara, PR & 2552 & 4835 & o Straube, 1990 \\
\hline 44 Salto do Piraí, SC & 2618 & 4902 & o Naumburg, 1939 \\
\hline 45 Blumenau, SC & 2656 & 4903 & $\begin{array}{l}\text { o Cory \& Hellmayr, } \\
1924\end{array}$ \\
\hline 46 Lagoa do Forno, RS & 2920 & 4953 & o Naumburg, 1939 \\
\hline 47 Lagoa do Jacaré, Torres, RS & 2920 & 4949 & * Belton, 1985 \\
\hline 48 Faz. Pontal, Osório, RS & 2947 & 5009 & * MNRJ \\
\hline
\end{tabular}

Myrmotherula minor (Salvadori's Antwren)

1 Santa Teresa, ES

2 Chaves, Santa Leopoldina, ES

3 Jatiboca, ES

4 Nova Lombardia Biol. Reserve, ES

5 Raposo, Itaperuna, RJ

6 Faz. Nova Aurora, Muriaé, MG

7 Cantagalo, RJ

8 Faz. União, Rocha Leão, RJ

9 Poço das Antas Biol. Reserve, RJ

10 Tingua Biological Reserve, RJ

11 Angra dos Reis, RJ

12 Tarituba, Parati, RJ

13 Pedra Branca, Parati, RJ

14 Ubatuba, SP

15 Corcovado, Ubatuba, SP
1955

2002

2025

2030

2104

2106

2158

2223

2235

2236

2300

2302

2313

2326

2329
4036

4039

4055

4035

4204

4233

4222

4200

4217

4326

4418

4434

4446

4504

4511

o MNRJ
o MZUSP, MCZ
o MNRJ
TAP (in litt.)
JFP
o MNRJ
o Cabanis, 1874
JFP
Scott \& Brooke, 1985
Scott \& Brooke, 1985
Pacheco, 1988
* BMW
o MNRJ
* Iher. \& Ihering, 1907
* BMW




\begin{tabular}{|c|c|c|c|}
\hline \multirow[t]{2}{*}{ Locality } & \multicolumn{2}{|c|}{ Coordinates } & \multirow[t]{2}{*}{ Source } \\
\hline & Lat.S & Long.W & \\
\hline $\begin{array}{l}16 \text { Boracéia Field Station } \\
\text { (MZUSP), SP }\end{array}$ & 2339 & 4554 & DFS (in litt.) \\
\hline 17 Varjão do Guaratuba, SP & 2345 & 4555 & ${ }^{*}$ MZUSP \\
\hline 18 Alto da Serra, SP & 2347 & 4619 & $\begin{array}{l}\text { o Cory \& Hellmayr, } \\
1924\end{array}$ \\
\hline 19 São Sebastião, SP & 2348 & 4525 & o Iher. \& Ihering, 1907 \\
\hline 20 Piassaguera, SP & $235^{\circ}$ & 4623 & o $M C Z$ \\
\hline 21 Estação Eng. Ferraz, SP & 2359 & 4636 & o MZUSP \\
\hline 22 Pedro de Toledo, SP & 2417 & 4714 & o CMNH \\
\hline $\begin{array}{l}23 \text { Hansa-Humboldt (= Corupá), } \\
\text { SC }\end{array}$ & 2626 & 4914 & o MNRJ \\
\hline \multicolumn{4}{|c|}{ Myrmotherula urosticta (Band-tailed Antwren) } \\
\hline I $25 \mathrm{~km} \mathrm{~N}$ Valença, BA & 1308 & 3904 & * BMW and JFP \\
\hline 2 Cajazeiras, BA & 1424 & 3951 & o Naumburg, 1939 \\
\hline 3 Faz. Ditosa, Itabuna, BA & 1448 & 3916 & o Lima, 1921 \\
\hline 4 Rib. Fortuna, Ilhéus, BA & 1449 & 3902 & o MNRJ \\
\hline 5 Faz. Pontal, Ilhéus, BA & $145^{\circ}$ & 3901 & o Lima, 1921 \\
\hline 6 Itatingui, BA & 1511 & 3918 & BMW \\
\hline 7 Una Biological Reserve, BA & 1513 & 3902 & LPG (in litt.) \\
\hline 8 Faz. Santiago, Belmonte, BA & 1551 & 3854 & o Lima, 1921 \\
\hline $\begin{array}{l}9 \text { Gregorio Bondar, Barrolândia, } \\
\text { BA }\end{array}$ & 1605 & 3913 & LPG (in litt.) \\
\hline $\begin{array}{l}10 \text { Reserva Pau Brasil, Porto } \\
\text { Seguro, BA }\end{array}$ & 1626 & 3905 & * BMW \\
\hline $\begin{array}{l}11 \text { Monte Pascoal National Park, } \\
\text { BA }\end{array}$ & 1645 & 3908 & LPG (in litt.) \\
\hline 12 Cupido, Linhares, ES & 1904 & 4008 & o MNRJ \\
\hline $\begin{array}{l}13 \text { Sooretama Biological Reserve, } \\
\text { ES }\end{array}$ & 1910 & 4000 & $\begin{array}{l}* \text { Scott and Brooke, } \\
1985\end{array}$ \\
\hline $\begin{array}{l}\text { 14 Faz. Santana, Lagoa Juparanã, } \\
\text { ES }\end{array}$ & 1922 & 4007 & o MNRJ \\
\hline 15 Reserva CVRD, Linhares, ES & 1930 & 4000 & JFP \\
\hline $\begin{array}{l}16 \text { Faz. da Serra, Baixo Guandu, } \\
\text { ES }\end{array}$ & 1930 & 4100 & o MNRJ \\
\hline 17 São Benedito, $\mathrm{MG}$ & 1930 & 4116 & o Naumburg, 1939 \\
\hline I8 Baixo Guandu, ES & 1931 & 4101 & o Naumburg, 1939 \\
\hline 19 Lagoa Juparanã, ES & 1935 & 4018 & o Naumburg, 1939 \\
\hline 20 Pau Gigante (= Ibiraçú), ES & 1950 & 4022 & o Iher. \& Ihering, 1907 \\
\hline $\begin{array}{l}21 \text { Mocotó, Desengano State Park, } \\
\text { RJ }\end{array}$ & 2150 & 4145 & JFP \\
\hline 22 Faz. União, Rocha Leão, RJ & 2223 & 4200 & * JFP \& PSF \\
\hline
\end{tabular}




\section{References}

Bege, L. A. R. and Marterer, B. T. P. (1991) Conservação da avifauna na Região Sul do Estado de Santa Catarina. Florianópolis: FATMA.

Belton, W. (1985) Birds of Rio Grande do Sul, Brazil. Part 2. Formicariidae through Corvidae. Bull. Amer. Mus. Nat. Hist. 180: 1-242.

Bernardes, A. T., Machado, A. B. M. and Rylands, A. B. (1990) Fauna brasileira ameaçada de extinção/Brazilian Fauna threatened with extinction. Belo Horizonte: Fundação Biodiversitas para a Conservação da Diversidade Biológica.

Cabanis, J. (1874) Uebersicht der von Herrn Carl Euler im District Cantagallo, Provinz Rio de Janeiro, gesammelten Vögel. J. Orn. 22: 81-90, 225-231.

Caldeiron, S. S. (1993) Recursos naturais e meio ambiente: uma visão do Brasil. Rio de Janeiro: IBGE, Departamento de Recursos Naturais e Estudos Ambientais.

Câmara, I. G. (1991) Plano de ação para a Mata Atlântica. Fundação SOS Mata Atlântica, Sociedade Brasileira de Proteção Ambiental and World Wildlife Fund. Unpublished report.

Carauta, J. P. P. and Rocha, E. S. F. (1988) Conservação da flora no trecho fluminense da bacia hidrográfica do rio Paraíba do Sul. Albertoa 1: 85-136.

Collar, N. J., Gonzaga, L. P., Krabbe, N., Madroño Nieto, A., Naranjo, L. G., Parker, T. A. and Wege, D. C. (1992) Threatened birds of the Americas: the ICBP/IUCN Red Data Book. Third edition (part 2). Cambridge, U.K.: International Council for Bird Preservation.

Cory, C. B. and Hellmayr, C. E. (1924) Catalogue of birds of the Americas (Part 3). Field Mus. Nat. Hist., zool. ser. 13: 1-369.

Euler, C. (1900) Descripção de ninhos e ovos das aves do Brazil. Rev. Mus. Paul. 4: 9148 .

Fonseca, G. A. B. (1985) The vanishing Brazilian Atlantic forest. Biol. Conserv. 34: 17-34.

Fundação SOS Mata Atlântica (1990) Anais da Reunião Nacional sobre a Proteção dos Ecossistemas Naturais da Mata Atlântica Atibaia: Workshop Mata Atlântica-Problemas, Diretrizes e Estratégias de Conservação.

Gonzaga, L. P. (1988) A new antwren (Myrmotherula) from southeastern Brazil. Bull. Brit. Orn. Club 108: 132-135.

Gonzaga, L. P., Scott, D. A. and Collar, N. J. (1986) The status and birds of some forest fragments in eastern Brazil. Unpublished.

IBDF (1981) Plano de manejo Reserva Biológica de Sooretama. Brasilia: Ed. Gráfica Brasiliana.

Ihering, H. and Thering, R. (1907) As aves do Brazil: catálogos da fauna brazileira, 1. São Paulo: Museu Paulista.

Isler, M. L. (in press) A geographic information system for the Neotropics. American Ornithologists' Union (Orn. Monogr.)

Lima, J. L. (1921) Aves colligidas nos estados de São Paulo, Matto Grosso e Bahia com algumas formas novas. Rev. Mus. Paul. 12: 91-106.

Meyer de Schauensee, R. (1966) The species of birds of South America and their distribution. Philadelphia: Academy of Natural Sciences of Philadelphia, Livingston Publishing Co.

Naumburg, E. M. B. (1939) Studies of birds from eastern Brazil and Paraguay, based on a collection made by Emil Kaempfer. Bull. Amer. Mus. Nat. Hist. 76: $231-276$.

Oren, D. C. (1992) Conservação da natureza na Amazônia Brasileira: uma orientação sobre prioridades baseada em aves. Bol. Mus. Para. Emilio Goeldi 8: 259-268.

Pacheco, J. F. (1988) Black-hooded Antwren Formicivora [Myrmotherula] erythronotos re-discovered in Brazil. Bull. Brit. Orn. Club 108: 179-182.

Pacheco, J. F., Parrini, R. and Carvalho, C. E. S. (1993) A lista de aves do Espírito Santo a partir de uma análise crítica sobre os trabalhos de Augusto Ruschi. In Resumos III Congr. Bras. Ornitologia. Pelotas: Editora Univ. Católica de Pelotas. 
Paynter, R. A., Jr and Traylor, M. A., Jr (1991) Ornithological gazetteer of Brazil. Cambridge, Mass.: Harvard University Press.

Pelzeln, A. (1868) Zur Onithologie Brasiliens: Resultate von Johann Natterers Reisen in den Jahren 1817 bis 1835 . Wien: Druck und Verlag von Pichler's Witwe \& Sohn.

Pinto, O. M. O. (1938) Catálogo das aves do Brasil e lista dos exemplares que as representam no Museu Paulista. Revta. Mus. Paul. 22: 1-566.

Pinto, O. M. O. (1945) Cinquenta anos de investigação ornitológica. Arq. Zool. São Paulo 4: $26 \mathrm{I}-340$.

Ruschi, A. (1953) Lista das aves do estado do Espírito Santo. Bol. Mus. Biol. Prof. Mello-Leitão, zool. 11: 1-21.

Scott, D. A. and Brooke, M. de L. (1985) The endangered avifauna of southeastern Brazil: a report on the BOU/WWF Expeditions of $1980 / 81$ and $1981 / 82$. Pp.115-139 in A. W. Diamond and T. E. Lovejoy, eds. Conservation of tropical forest birds. Cambridge, U.K.: International Council for Bird Preservation (Techn. Publ. 4).

Sharpe, R. B. (1906) Birds. Pp.79-516 in British Museum of Natural History (1904-1912) The history of the collection contained in the Natural History departments of the British Museum (vol. 2). London: British Museum (Natural History).

Sibley, C. G. and Monroe, B. L. Ir (1990) Distribution and taxonomy of birds of the world. New Haven: Yale University Press.

Sick, H. (1985) Ornitologia brasileira, uma introdução. Brasília: Editora Universidade de Brasília.

Sick, H. (1993) Birds in Brazil: a natural history. Princeton: Princeton University Press.

Sick, H. and Pabst, L. F. (1968) As aves do Rio de Janeiro (Guanabara). Arq. Mus. Nac. Rio de Janeiro 53: 99-160.

Snethlage, E. (1908) Eine Vogelsammlung vom Rio Purus, Brasilien. J. Orn. 56: 7-24.

Snow, D. W. (1982) The cotingas. London: British Museum (Natural History).

Straube, F. C. (1990) Conservação de aves no litoral-sul do estado do Paraná (Brasil). Arq. Biol. Tecnol. 33: 159-173.

Teixeira, D. M. (1987) Notas sobre o "gravatazeiro", Rhopornis ardesiaca (Wied, 1831) (Aves, Formicariidae). Revta. Bras. Biol. 47: 409-414.

Teixeira, D. M. and Gonzaga, L. P. (1985) Uma nova subespécie de Myrmotherula unicolor (Ménétries, 1835) (Passeriformes, Formicariidae) do Nordeste do Brasil. Bol. Mus. Nac. Rio de Janeiro n.s. 310: 1-16.

Vanzolini, P. E. (1992) A supplement to the Ornithological gazetteer of Brazil. São Paulo: Museu de Zoologia Universidade de São Paulo.

Willis, E. O. and Oniki, Y. (1981) Levantamento preliminar de aves em treze áreas do Estado de São Paulo. Reita. Bras. Biol. 41: 121-135.

Willis, E. O. and Oniki, Y. (1992) A new Phylloscartes (Tyrannidae) from southeastern Brazil. Bull. Brit. Orn. Club 112: 158-165.

Zimmer, J. T. (1932) Studies of Peruvian birds, 4. The genus Myrmotherula in Peru, with notes on extralimital forms, part 2. Amer. Mus. Novit. 524.

\section{BRET M. WHITNEY and JOSÉ FERNANDO PACHECO}

Lab. Omitologia, Dep. Zoologia, Instituto de Biologia-CCS, Cidade Universitária, Rio de Janeiro-RJ, 21944-970, Brazil. 